\title{
Slow dissent and the emotional geographies of resistance
} Amber Murrey

\author{
Anger, grief, regret and shame are some of the myriad ways that people narrate a decade of life along \\ the Chad-Cameroon Oil Pipeline. These stories reveal a perceptive and collective socio-political \\ awareness situated within multifaceted emotional geographies of resistance. In spite of resistance \\ narratives, explicit and collective resistance practices remain uncommon. As people struggle and live \\ within composite landscapes of structural violence along the pipeline, particular processes and mechanisms \\ of uneven power influence the tendency for resistance struggles to be slow, impromptu or \\ labour based. In this comparative ethnographic analysis, I consider the political environment that \\ shapes socio-political emotional ties in Nanga, particularly its socio-political positioning as 'the village \\ of the First Lady'. In this case, people in proximate positions vis-à-vis the ruling family experience \\ heightened oppression(s) and dispossession(s), at the same time that they report feeling little political \\ recourse. In Kribi, on the other hand, responses to the pipeline can be described as defiant withdrawals, \\ demonstrated through a series of unconnected refusals. Although resistance practices along \\ the pipeline have not been visible or successful in an established sense, emotional geographies of \\ resistance elucidate long-term struggles to survive (i.e., slow dissent), including the accumulation \\ of a collective emotional consciousness grounded in an awareness of historical patterns of injustice.
}

Keywords: Cameroon, anger, shame, emotional geographies, oil pipeline, resistance

Can the pipeline not explode? Can it not be broken?!

Elie M., community member whose farm was destroyed during the construction of the ChadCameroon Oil Pipeline, Nanga-Eboko, Cameroon, 2012, nine years after the construction of the pipeline

\section{Introduction}

In this article I outline how an attention to emotional geographies illuminates meaningful aspects of experiences of violence and what I tentatively posit as slow dissent in two communities along the Chad-Cameroon Petroleum Development Pipeline Project (hereafter the Chad-Cameroon Oil Pipeline or the pipeline). My aim is to contribute to broader discussions on the emotionalities of exclusion and oppression (particularly collective emotions) and their roles in resistance(s) in places affected by pervasive resource (neo)imperialism. To do so, I offer articulations of some of the emotional geographies that emerged during seven and a half months of ethnographic fieldwork in Nanga-Eboko (henceforth Nanga) and Kribi, Cameroon.1

This article emerges out of a larger scholar-activist-artist project on the social, emotional and environmental transformations effected by the oil pipeline within the broader geopolitical struggles over capital accumulation within the region (Murrey, 2015b). The effects and experiences of one dispossessing project are exacerbated by the effects of another and yet another, so that not only are the communities of Nanga and Kribi tied together by their proximity to an oil pipeline (and subsequent experiences of displacement in-place and land dispossession), they are also united by the concurrent unfolding of other large-scale capitalist-intensive extractive projects, among them a rice plantation, a deep sea port, road construction projects and extensive logging projects (Murrey, 2015a; Figure 1). If we work outward from the stories recounted by people in Nanga and Kribi, which connect disparate patterns and processes of extraction and exploitation, the oil pipeline exists within and reinforces a larger context of structural violence. The pipeline is not perceived as an exceptional case of state-sponsored and corporate-backed land and resource theft under the guise of development. Instead, the pipeline is narrated as one project in a long line of similarly experienced and similarly understood projects. A framework of structural violence captures the pipeline's situated-ness within, as well as its contributions to, larger structural exclusions and dispossessions experienced by people in Nanga and Kribi. As I note elsewhere, narratives of the pipeline often contain the echoes of collective memories of earlier violence, particularly colonial violence, which people call upon to characterize present-day suffering (Murrey, 2015a).

Rob Nixon (2011) presents a fresh take on structural violence (particularly its social and ecological interfaces) as 'slow' violence, violence that slowly unfolds across the environment and within the normalized operations of globalized imperialist capitalism. In my work I am concerned with how people (might) slowly resist unfolding structural violence(s). 
I find it useful to allocate a similar weight to the longevity of the social processes of resistance: something we might imagine as slow dissent. Slow dissent is not understood as a continuum

Figure 1. The never-ending scramble. In this image, overlapping infrastructural and extractive projects unfold across the Cameroonian landscape, including (in clockwise direction starting from top left) the World Bank-funded Lom Pangar Hydroelectric Dam Project, which required the rerouting of a portion of the Chad-

Cameroon Oil Pipeline; a gravel pit and cement plant near Nanga; and the Kribi Deep Sea Port Project, which displaced 5000 people. The man-octopus represents the neocolonial monster, perpetually snatching and grabbing (the octopus figure is adapted from an anonymous American cartoon from 1882 titled 'The Devilfish in Egyptian Waters'). Photographs by author, 2012-13.

(i.e., as a facile movement from violence to emancipation) but rather recognition of the temporal potentials within emotional narratives arising from experiences of dispossession. Slow dissent is a resistance with perseverance, in spite of enormous ruptures and pressures, and the density to disrupt the prolonged temporality and multispatiality of multidimensional and compounded structural violence. Such dissent is wisely protracted rather than fast, organized and/or (highly) visible.

Emotional geographies are central to my understanding of slow dissent. Simply put, acts of resistance have emotional roots. Exclusively political, social or economic analyses do not suffice to explain human resistance (Hibou, 2012). In Kribi, the community response to the pipeline can be described as a defiant withdrawal, demonstrated through a series of unconnected refusals within emotional geographies of anger and shame. In Nanga, a complex political environment-including the town's heritage as 'the village of the First Lady' and its association with the presidential family - evokes emotions of loyalty and responsibility alongside anger. Politico-ethnic affinities and a fear of the repercussions of resistance actions are two factors that restrict imaginaries of possible action. Work in these two communities reveals a paradox of collective narratives of resistance that identify mistreatment, speak against dispossessions and vilify the consortium and local actors who profited fromthe pipeline. All the while dissent is slow - it is intermittent, unfulfilled, quiet, oscillating. My concept of slow dissent places emphasis on potential within emotional narratives (of anger, shame, loss, regret, hope), as people reflect upon the pipeline in retrospect and insist that they will act differently in the future.

Hegemonic powers reinforce and consolidate power by mobilizing enormous revenuesin this case, petro-wealth from the pipeline - to bolster structural dominance, including advancing the militarization of Chad and Cameroon with pipeline profits (Taguem Fah, 2007). This militarization, in turn, reinforces material oppressions and stymies future resistance efforts (Figure 2).2 Against an onslaught of multidimensional structural violence, there is no one moment or one project that is the inauguration of resistance; rather, there is an emotionally saturated slow dissent-one that is punctuated with discontinuity and fracturing(s) - with the potential to exert pressures against systemic forces over time. Indeed, despite dense emotional geographies of anger and frustration, explicit resistance practices remain uncommon in Kribi and Nanga, in part due to the fracturing of collectivities in geographies of structural violence. Attending to the messiness of resistance temporalities requires addressing such ambiguities, and as I discuss in the conclusion, practices of slow scholarship make it possible to attend more seriously to these ambiguities. The scholarship on slow dissent must itself be slow.

\section{Emotional geographies of slow dissent}

The 1990s witnessed a growing scholarly attention to the emotionality of politics and protest. There is now a rich body of interdisciplinary literature on the complex roles of emotions in socio-political processes. 3 This social science of emotion has shown that 'emotion has the power to transform the shape of our lives, expanding or contracting our horizons' (Bondi et al., 2007: 1). Emotions are integral to socio-political awareness and identity. Emotions frame action, shape consciousness and are mobilized, often collectively: 'they help produce and are produced by both connection (as solidarity, shared experience) and distance (geography, of class, of experience)' (Wright, 2012: 1115). Emotions shift throughout interactions between people (including dominant and nondominant people), places and environments. At the same time, emotions reify (dis)attachments and structure collective socio-political subjectivities. A focus on narratives allows some of the richness of human experience to remain in an examination of life amid compounded forms of structural violence (Murrey, 2015a), while emphasizing 
that emotional geographies are often both collectively felt and collectively generated (collective is understood here as occurring in at least half of my conversations in Nanga and Kribi (see Pettigrove \& Parsons, 2012)). Emotions emerge within communal settings over time, as one person's stories reverberate in the experiences of neighbours, friends and family members.

The concept of emotional geographies encompasses an understanding of broader socio-political geographies: emotional geographies are multiple, shifting, contested, ambiguous and multidimensional. Drawing from Bondi, Davidson and Smith, 'emotional geographies' are not understood as rigidly disciplinary (Bondi et al., 2007: 2) but rather as informed by 'a concern with the spatiality and temporality of emotions, with the way they coalesce around and within certain places... [because] emotions are produced in relations between and among people and environments' (Bondi et al., 2007: 3). Resistance emerges within geographies configured through unique interplays of sociopolitical and economic actors, actions, mechanisms and histories.

Resistance is a broad category encapsulating concrete and creative social, political, cultural and economic actions through which people struggle, sometimes unintentionally, to rework networks of power, create empowering counter-narratives and/or chip away at institutional and structural inequalities (Pile, 1997; Sharp et al., 2000). Such

Figure 2. A poem by the author. Text is adapted from World Bank website and the Bank's International Advisory Board, and the World Bank's logo is visible behind the text (International Advisory Group, 2009: 5). Words in the popular lingua franca Camfranglais include 'ndjeum' (fat, big), 'benguistes' (very loosely, 'Westerner', but also a Cameroonian living abroad, often one who has adopted a Western lifestyle), 'tchop' (eat) and 'jusqu'à bolé ' (to finish something off). In the background, a COTCO guard stands near the pipeline valve station, outside Nanga. Photograph by author, 2012.

actions may be large or small scale, collective or individual, hidden or observed. Struggles occur in the quiet of the everyday and continue for years. Rather than being fast or immediately tangible through a concrete episode, dissent is understood here as the time-intensive cultivating and building of a shared (multivocal) geography of collective empowerment from which overt or inadvertent, direct or indirect, or sporadic or organized acts of dissent might(and often do) emerge. This means that fluctuating potentials and spatialities are important for the movement and building of dissent.

The notion of building - as in building the emotional, psychological and spatial foundations for resistance-highlights the centrality of movement over time and space. There is no unified or predetermined route of struggle; rather there are multiple and simultaneous routes, and they are always changing across time and space. This multiplicity does not immobilize resistance efforts. Asef Bayat (2010) argues that simultaneous and concerted pressures of multiple actors (what are otherwise characterized as unplanned, uncoordinated and scarcely perceptible microactions) create a density of resistance that, together, are sufficient to challenge systemic injustices. Slow dissent emphasizes the capacity and will of people to live fully and is revealed in movement, potential and density of practice across space and time. Fragments of movements and potentials are embedded within emotional narratives of suffering. Drawing from an understanding of resistance as slow and informed by collective emotional geographies, here I explore the fluid interplay between structural violence, dissent and emotion along the Chad-Cameroon Oil Pipeline. Emotional narratives reveal complex and developed socio-political awareness that gestures towards (emergent, latent, fractured) slow dissent.

Feminist geographers identify a pervasive Eurocentrism in the interpretation of emotion, including a tendency to universalize and a failure to acknowledge uneven power relations (Anderson \& Smith, 2001; Toila-Kelly, 2006; Sharp, 2009). Rather, people's shifting positioning(s) within socio-political environments occurs alongside the complex interplay of ambiguous emotive and psychological senses. Encounters and environments, in turn, shape and inform emotional geographies. In central and southern Cameroon, for example, public spaces are landscapes for vivid expressions of both individual and collective emotional scripts, including disgust, anger, attraction, affection, humour, grief and shame or disgrace. These dynamic emotional scripts are variously characterized by loudness of voice, laughter, emphatic use of the 'tchip' or 'piaff' sounds 
(made by the smacking or clicking noise made by movement of the tongue against the soft palate and lips against teeth), nonverbal modes of communication such as clapping, distinctive hand signals or shrugging (often to reinforce a particular point being made verbally), and the symbolic re-establishment of affectionate (nonsexual) relationships via the joining of hands, for example. Emotions are amplified within particular social environments, including the presence of empathetic spectators or group members who have experienced similar oppressions and traumas (there is a complex relationship between emotions and collectives that cannot be fully explored here; for one, emotions such as fear and laughter are sometimes contagious).

Emotional geographies are not universal, static or measurable; rather, they are complex, pluriform and shifting - but also ubiquitous. Following from the complexity and fluidity inherent in emotional geographies, a framework for engaging them must necessarily be fluid and multifaceted. My project is grounded by a decolonial concern with the tensions (often gendered and racialized) and institutional frameworks that define and create boundaries within academic knowledge, particularly how these boundaries exclude or disapprove of nonofficial or nonexpert narratives, such as emotion. I frame my project as a 'mixtape', a means of bringing attention to creative practice as a form of politics, in this case in pursuit of an alternate (nondominant) intellectual aesthetic that allows us to - slowly, tentatively, cautiously — get at the complexities, fragilities and emotionalities that characterize being-in-the-world. Indigenous, feminist and postcolonial scholars have worked to cultivate vernaculars and ways of writing or knowing that capture some of the uncertainties, fragilities and messiness of life (Gibson, 2006; Gilmartin, 2009; Eshun \& Madge, 2012; Kara, 2015). Musical mixtapes, for example, engage with human experience through experimentations with form, politics, aesthetics and presence. Drawing inspiration from a mixtape imaginary, I mix and cut aesthetic forms (film, photography, poetry, narrative, theory) to introduce different, and even divergent, possibilities of understanding the noncoherent emotional landscapes of Kribi and Nanga.4

\section{'We are like these [plastic] chairs': pipe dreams of development}

Cameroon has a rich history of resistance (Murrey, 2012). Since formal independence in 1960 , the country has witnessed periodic waves of popular protest from its active civil society. By and large, resistance practices along the pipeline have not been formally organized or internationally visible and have tended to arise around issues of labour rights (see Murrey, 2015b for an examination of a labour dispute in Kribi; see Osuoka \& Zalik, 2010 as well as Hoinathy, 2013 for accounts of pipeline advocacy and negotiating by a network of international non-profit organizations). 5 Yet through emotional narratives, we perceive a potential building of long-term dissent alongside struggles to survive within composite geographies of structural violence.

At the time of construction (from October 2000 to December 2003), the USD 4.1 billion dollar Chad-Cameroon Oil Pipeline was the largest onshore private investment project in sub-Saharan Africa (the project includes the pipeline, hundreds of production and water injection wells, three pump reduction stations, a pressure reduction station, ancillary facilities, an offshore marine export terminal facility, an offloading vessel and the underwater marine pipeline (International Advisory Group, 2009: 5)). The pipeline project is a public-private partnership. It includes a consortium made up of ExxonMobil (operator with 40 per cent of shares), Petronas (35 per cent) and Chevron Texaco (which sold its total shares of 25 per cent in June 2014 to Chad's national hydrocarbon company, La Société des Hydrocarbures du Tchad), along with the governments of Chad and Cameroon (with a combined 3 per cent stake in the pipeline portion of the project through the partial ownership of the portion of the pipeline in Cameroon, operated by the Cameroon Oil Transportation Company, S.A., i.e., COTCO, and the portion of the pipeline in Chad, operated by the Tchad Oil Transportation Company, S.A., i.e., TOTCO)6 and the World Bank Group (which provided 4 per cent of the investment capital for the project; 7 see Esso Exploration and Production Chad, n.d.; World Bank, n.d.). The majority of the pipeline, 890 of its $1070 \mathrm{~km}$, runs through Cameroon (Figure 3).

As the project was announced, an international community of journalists, scholars and non-profit advocates was increasingly vocal against with top-down models of modernization, and there was a growing awareness (and subsequent condemnation) of the so-called resource curse. 8 This mounting international consciousness of oil-related ecological 
and social destruction arouse around a series of oil-related disasters, including the Idjerhe pipeline explosion on 17 October 1998 in the Niger Delta, during which 700 to 1000 people were killed (Ola \& Eighemhenrio, 1998), and the extrajudicial killings of the Ogoni Nine in November 1995 for their criticism of Royal Dutch Shell in the Niger Delta (in fact, Shell was an original member of the Chad-Cameroon Oil Pipeline consortium but withdrew, along with Elf Aquitaine, in 1999). These dangers were not unknown to the World Bank, which had come under a wave of international protests in the early 1990s under the slogan 'fifty years is enough'. Protestors criticized the Bank's funding of ecologically and socially destructive projects and brought light to the Bank's systematic failure to put into effect its own poverty-reduction promises (Danaher, 1994; Toussaint, 2008). Despite these protests, the Bank performed a crucial role in providing 'political risk insurance' for the oil companies in the face of environmental and social concerns (Nguiffo, 2002: 3).

The consortium, led by the Bank, promoted the pipeline as the project that would end the resource curse through the implementation of mechanisms for poverty reduction. The press release by World Bank's private sector affiliate announcing the Bank's approval of the plan described the project as 'an unprecedented framework to transform oil wealth into direct benefits for the poor, the vulnerable and the environment' (International Finance Corporation, 2001). A substantial international publicity

Figure 3. A map showing the Chad-Cameroon Oil Pipeline running through Cameroon. 230 Amber Murrey

campaign championed the consortium's consultations with 'local' stakeholders. ExxonMobil described the level of public consultation as 'unprecedented': 21000 consultation meetings involving 300000 people, in what ExxonMobil referred to as 'the largest consultation program of its type ever undertaken in Africa and perhaps the world' (ExxonMobil, 2004: 38). These consultations fostered optimism for the project's developmental potentials among people living along the pipeline, including those in Kribi and Nanga, where people awaited the consortium's grandiose promises of progress. However, this language of developmentwas strategically sanitized and decontextualized from the socio-political realities in Chad and Cameroon (see Jackson, 2011, for an analysis of this discourse as 'neoliberal corporate spectacle'). Indeed, at the time of construction, Cameroonians were, by and large, dispirited by national politics (Fombad \& Fonyam, 2004; Mbuagbo \& Mbe Akoko, 2004). Twenty years of neoliberal policies had resulted in re-entrenchments of poverty, joblessness and corruption that harkened back to the colonial period. In the decade that the engineering details of the pipeline were being negotiated, the Cameroonian President, Paul Biya, was occupied with a violent suppression of movements for the democratization of Cameroon (Fombad \& Fonyam, 2004). For example, Opération Ville Mortes (Operation Ghost Towns), a series of youth-led nationwide campaigns for a multiparty system shut down major cities in the 1990s (Malaquais, 2002), and newspaper accounts detailed the habitual use of intimidation and excessive lethal force by paramilitary gendarmes in the disbanding of opposition meetings and protests (Fombad \& Fonyam, 2004). The 1992 presidential election was widely acknowledged by observers as rigged, including by the US State Department, which suspended USD 14 million in aid and closed its USAID offices in Cameroon after the armed forces were deployed to violently contain protestors (Amin, 2004: 168). Biya's track record of arresting and imprisoning journalists, dissidents, activists and former political allies was well documented throughout the period that the pipeline was being negotiated, engineered and constructed (this is evinced through reports published by Amnesty International, Catholic Relief Services, Human Rights Watch, Transparency International and the US State Department).

Despite contentions from the Bank and the oil consortium that poverty alleviation and development ventures would be coupled with commercial and capitalist interests in a manner beneficial for all parties involved, the pipeline project directly and indirectly augmented and reinforced structures of oppression, militarism and neoliberalism in both Cameroon and Chad (Murrey, 2015a; 2015c). On 9 September 2008, a mere four days after Chad repaid in full its loans incurred for pipeline-related funding (USD 39.5 million for its shares in TOTCO), the Bank announced that it was unable to continue its support for the project, because of the misallocation of pipeline profits by the Chadian governmentnamely the use of proceeds for the procurement of arms and weapons (World 
Bank, 2008). This announcement occurred alongside an agreement between the Bank and the government of Chad for the Chadian government to repay USD 140 million in project loans to the Bank ahead of schedule.

On the ground, the discourse of development had perpetuated expectations of wealth and promises of prosperity that amounted to littlemore than painful pipe dreams (i.e., fanciful illusions, as in those generated in an opium daze) for the people dispossessed of land and livelihood along the pipeline's right of way (see Adunbi, 2013 for a related analysis of how pipelines represent ancestral promises of wealth in the Niger Delta region). These pipe dreams triggered powerful emotional reactions from those who were targeted by the consortium's publicity campaigns (Figure 4).

In Kribi and Nanga, the majority of people I spoke with reported feeling alternately reduced, dismissed and/or taken advantage of by the oil consortium and described how they were undervalued by the consortium's protocols and procedures. Interactions with consortium officials often evoked a personal and collective shame in the people, who described themselves as being 'duped', 'had' and 'scammed' (d'être escroqué). The consortium's plastic objects of 'reimbursement' and 'compensation' added insult to injury by littering the landscape with symbols of this disposability. These cheap, easily breakable objects of reimbursement - plastic patio chairs, disposable plastic sacks and small plastic buckets - became symbols of the consortium's dismissal of and little regard for the people along the pipeline (Figure 5). During a conversation with an elderly woman, Mama Marceline, 9 outside Kribi, she told me, 'They treat us like these [plastic] chairs - garbage' (pers. comm., Kribi, February 2013). She pointed to the dust-stained plastic patio chair that had been part of the COTCO community reimbursement in her village. One of the chair's legs had long since fractured, and someone had weaved it back together with rusting wire. Mama Marceline and her two sisters sat on the ground throughout our conversation. The chair sat nearby, conspicuously empty.

According to resolute notions of what constitutes respectful comportment in the rural areas of Cameroon (Murrey, 2015c) the consortium's (ostensible) failure to care was seen as grossly pernicious and tantamount to theft. These feelings of abandonment were aggravated by concurrent problems of poverty (including joblessness and periodic illness) and political impotence. Encounters with oil pipe dreams illuminate collective emotionalities of shame and anger evoked by a sense of disposability.

Figure 4. Various publicity materials of the pipeline project. (a) 'Hooray for the pipeline!' reads the cover page of a pamphlet that had been carefully guarded by a family outside of Nanga. (b) These pipe dreams triggered powerful emotive reactions in the populations along the pipeline route, who were targeted by the consortium's publicity campaigns. This consortium-produced pamphlet depicts two farmers discussing their soon-to-arrive profits from the pipeline. (c) A gathering of government officials to celebrate the finalization of pipeline construction (First Lady Biya can be seen in yellow), Cameroon, 2004. Source: Esso Exploration and Production Chad, Inc.

\section{Anger and shame in Kribi}

With a population of 93246 (as of 2005), Kribi is located on the Atlantic coast, near the pipeline pressure reduction station, in southern Cameroon. Tourism and artisanal fishing dominate Kribi's economy (Figure 6). Small-scale agricultural cultivation, done mostly by women, is the principal source of food. Mixed-crop subsistence farmers, who practise traditional slash-and-burn agriculture, inhabit Kribi's evergreen tropical forests. People have strong historical and psychological ties to the land that are affirmed through customary tenure. The psychological and emotional prominence of land emerged as an important theme early on in my conversations with community members.

Jojo told me that the people were never consulted about the location of the pump reducing station in Mpango, several kilometres outside of Kribi. He explained:

This was the case despite the fact that we had already opened a file about the ownership of that land. They never asked us anything and they never reimbursed us anything for the loss. They just closed the file that we had opened about village ownership. Even today, they continue to make extensions and they never tell us anything about it. I know that even if we had legal papers they could have cancelled them. Even though the land is the government's [by law], there is a psychological shame [une honte psychologique] that should be reimbursed (university student and real estate agent, pers. comm., Kribi, January 2013). 
Jojo's words suggest an emotional geography that shifted during the appropriation of land. His words reveal a dissonance between capitalist-intensive projects and complex

Figure 5. A Cameroonian non-governmental organization, Foundation Camerounaise pour une Action

Rationalisée des Femmes sur l'Environnement (FOCARFE), carefully documents faulty equipment and subpar

materials distributed by COTCO in their July 2005 newsletter. FOCARFE has worked for over a decade on

behalf of people affected by the pipeline. Source: FOCARFE.

emotional and psychological attachments to place. He spoke uninterrupted for several minutes as I listened, nodding from time to time.

Here, we have no health centre; we have no [functioning] water wells...Even the school, it was us, the villagers, who started the process to build the school and...COTCO [only] came in and completed the funds. It is lamentable...It hurts so much.

He stopped briefly, then continued.

We don't like to even speak of [the pipeline]. As long as the [pressure reducing] station is there, I tell you that it is political. You know, they employ other black people [at the station] - other Cameroonians, but [they are] Anglophones [in a predominantly francophone region] - to guard and protect it, to keep us out... but one day we will wake up [se lever]. People have to become conscious one day.

Jojo's words illustrate the splintering of local collectives through particular ethnicpolitical attachments and, similar to those of the community in Nanga, reveal the ways in which domination is effected through a fracturing of collective emotional consciousness in-place. While Jojo's experiences are not representative of all the inhabitants of Kribi, his emphasis on 'psychological shame' indicates a personalization of loss that was echoed by his neighbours.

As Jojo and I spoke he periodically illuminated his cell phone to check the time. He had his cousin's bereavement ceremony, or deuil, to attend. He ended our conversation,

Figure 6. Kribi's beaches have a central place in livelihoods and landscapes. (a) A painted signpost identifying a popular tourist destination, Hotel Tara Plage. (b) Kribi's beautiful Tara Beach. (c) A view of the artisanal fisherman's port in Kribi. There have been two reported oil spills off Kribi's shores since oil pumping began in 2003. Photographs by author, 2013.

'I have a deuil to go to; otherwise, I would have shown you the obstacles that [COTCO has] placed along the pipeline to make sure we cannot even go onto our land anymore.' This was not the first time an interview was cancelled, postponed or concluded prematurely for grieving. Conversations about the pipeline occurred within broader emotional geographies of loss, suffering and bereavement.

The appropriation of land along the pipeline was rendered all the more insulting, according to Jojo, because the village had already filed documents requesting legal ownership of the land. The dossier was prematurely closed and never acknowledged by the state or the oil consortium. The loss of land is coupled with feelings of anger at the dismissal of people, who, as Jojo reiterated, have no local health clinic and no employment prospects, whose water sources were contaminated during the pipeline construction and whose schoolroom is credited to COTCO, even though the villagers pooled money to begin its construction (Murrey, forthcoming). His narrative denotes a magnitude of loss that is not easily calculable. Land loss involves a psychological and physical displacement from past, present and future, one that people encounter and re-encounter every day, as they pass by places that have been appropriated, transformed or destroyed for extractive and infrastructurally violent projects. Andile Mngxitama (2013: 10) describes the loss of land in Africa as 'a void and a great menacing silence' and challenges the rhetoric that 'positions land theft in the realm of material dispossession'. Instead, he argues that land theft is a central part of the African experience of modernity. He writes:

land [is] the source of life and death; it [is]...like a mother who gives her children sustenance without which they would perish... it gives us life and when we die it takes us back...can this other loss be named, and the conditions of redress concretised in a set of demands that speak the language of rights and fit into the established lexicon of the losses that can be repaired? (Mngxitama, 2013: 10). 
Mngxitama interrogates the fundamental framings of conversations and debates on land expropriations in Africa. Land dispossession is embedded within the rhetoric of coloniality, including the principles of imminent domain, corporate effectiveness and the maximization of profit (Figure 7). This lens is so dominant that even conceiving the emotional and psychological magnitude of loss seems unmanageable within liberal frameworks of individual rights or human rights standards. The official narratives enable dispossession, which allows the state to assert the value, cost and monetary reimbursement, and reify the earlier colonial dichotomy between useful and useless (utile and inutile) land.10 Emotional narratives - which centre on loss, community, psychological attachment, the belly, the body and nourishment — are at odds with the colonial and capitalist model of land as a vehicle for profit.

The response to this honte psychologique has been defiant withdrawal in Kribi, demonstrated through a series of unconnected refusals: sometimes the refusal to cultivate along the pipeline, sometimes the refusal to continue to receive COTCO representatives in villages and sometimes the refusal to work along the right of way for COTCO subcontractors. In a village near Kribi, for example, Nadine said:

[COTCO] comes only to recruit workers. Monday they paid the men [for clearing the pipeline right of way]. Normally, it is the chief that should choose the workers... but they don't even go through my husband [the Chief]. The other day they made [my husband] sign [an agreement regarding the amount of work and the payments made to workers] - I told him not to sign because they can use that to excuse any amount that they paid the workers, and we didn't even know [how much that was]...! What discouraged people was that sometimes they went two weeks without pay... I came... and found that he had already signed the paper. Otherwise I would have grabbed it and refused that he sign...! I leave here and walk how many kilometres to get water [because the pipeline destroyed our water source] (community member, pers. comm., village near Kribi, March 2013)?

Nadine's refusal to sign COTCO's paper reflects the trend for people in Kribi to express their displeasure with the project through withdrawal and refusal. These refusals signal movements towards disobedience, within a slow arc of dissent, as people refuse to consent to the demands of authority. Sharp et al. (2000: 10) describe refusals as significant, because through them people 'decline to supply the power-holders with the sources of their power'; moreover, when practised collectively, acts of refusal take on a density with the potential to create a weight of resistance against structural forces. While these responses were not orchestrated or organized along the pipeline, they signal an oscillating slow dissent informed by anger and shame.

\section{Anger and resignation in Nanga}

Nanga is the capital of the Haute-Sanaga in Cameroon's Centre Province and has a population of approximately 30000 (at the time of writing this Cameroon's national

Figure 7. (a) Chadian President, Idress Déby, at an inaugural event on 10 October 2003 celebrating oil flowing from Chad's Doba Basin through the Chad-Cameroon Oil Pipeline. Source: Esso Exploration and Production Chad, Inc. (b) 'Private state property'. Pipeline warning signs-Chad-Cameroon Oil Project, private state property - rust in the equatorial sunshine near Kribi. Photograph by author, 2013.

statistical database was last updated in 2005). The community of Nanga has low rates of education and literacy, low rates of electrification, high rates of out-migration among young people (aged 18-30) and close ethnic ties to Cameroon's dominant political party, the Rassemblement Démoratique du Peuple Camerounais (RDPC), a.k.a. Cameroon People's Democratic Movement (CPDM). Nanga-Eboko is renowned as the birthplace of the mother of the First Lady, Chantal Biya, and the town is commonly referred to as 'the village of Chantal Biya' (Figure 8). In part because of this connection with the president's family, people in Nanga described feelings of political fatalism, while others a strong sense of political-ethnic solidarity (Figures 9, 10).

Emotional narratives of the pipeline, while never uniform, can be broadly characterized as a begrudging acquiescence alongside anger, fear and disappointment. These emotions intersect with the broader emotional geographies of Nanga, including honour, respect and loyalty. People were conscious of their being exploited as a paradoxical result 
of their close proximity to power: because they were seen as aligned with the party in power, they were, paradoxically, abandoned by the state. For example, the state allocated funds for infrastructure projects in other politically, ethnically or religiously non-aligned places, to pacify those communities and weaken their resistance. Rather than demonstrating openly, people in Nanga mobilized quietly within small spaces (and places out of sight of dominant actors), for example by negotiating with their local chiefs for access to portions of the pipeline profits or by engaging in small-scale, individual acts designed to interrupt corporate plunder. The latter included, for example, the replanting of farm plots nearer the pipeline during the construction period, so as to ensure some measure of individual compensation.

One man was enraged after the consortium's promises of employment amounted to a mere four-day employment as a manual labourer. In response, he outsmarted COTCO bureaucrats during the pipeline construction period, particularly in the collection of wages. While in the queue awaiting his payment, he noted that wages were handed out according to the forfeit of each worker's badge. After receiving his or her (workers

Figure 8. A faded poster of First Lady Chantal Biya (a pull-out poster from the magazine, Jeune Afrique Économie) hangs on the wall of my bedroom in Nanga. Photograph by author, 2012.

were nearly exclusively men) cash payment, each worker deposited his badge in a receptacle adjacent to the payment desk. Then the man presented his badge for payment and after being paid in full, made an action as if he quickly tossed his badge in the receptacle, but actually he hid the badge on his person. A few hours later, the man Figure 9. (a) A portrait of President Paul Biya hangs in an examination room in the Chantal Biya Hospital in Nanga. (b) A campaign card featuring the popularized image and slogan of Paul Biya-'le choix du peuple/the people's choice'-hangs outside a home in Mpango (right). Photographs by author, 2012-13.

Figure 10. An excerpt from 'I went back tomy country', a poem written by the Cameroonian political activist and scholar, Dieudonné Enoh Meyomesse (and translated by Katerina Thomas), during his time in Kondengui Prison. The unsubstantiated charges against Meyomesse (robbery and attempting to organize a coup d'état) were dropped, and on 28 April 2015, he was released after three years of imprisonment. His 2015 interview with Serge Alain Otou on Dimanche Avec Vous (available on YouTube) reveals how significant cracks in the political administrative system allowed police officers and judicial officials to exercise agency against the regime and ensure that Meyomesse was not assassinated (despite orders to that effect) and was transferred from solitary confinement in a windowless cell in Bertoua to a lower-security holding cell in Kodengui. Note: Kamerun is the German spelling, used to demarcate the Cameroonian colony (i.e., 'protectorate') until World War I; after a violent war fought on Cameroonian soil for control of the territory, the colony was split into two and became the British and French 'Cameroons'.

presented himself in the queue for payment again and was allocated a second salarywhat amounted to approximately USD 125 . The memory of this event served to empower the man. This story was well known among his friends and provoked new laughter at each retelling.

In comparison, ExxonMobil is one of the largest and most profitable corporations in the world (it routinely ranks among the top ten of Forbes Global 2000) and has annual revenues of hundreds of billions of US dollars (its revenue was USD 340 billion in 2005). This man's tactic for doubling his salary occurred in a context where people routinely reported needing to pay bribes to even be considered for the temporary employment offered by the oil consortium. Derogy, my field partner, for example, was asked to pay a gumbo, or bribe, of USD 25 merely for applying for a temporary position with COTCO.

In Nanga, there was a disconnect between pride in being part of the extended family of the First Lady, on the one hand, and the realities of abandonment, dispossession and impoverishment, on the other. People insisted that Nanga and the surrounding villages are more acutely underdeveloped than those places occupied by political-ethnic groups that are perceived of as potential locations to catch fire politically (s'en flame). Places inhabited by political-ethnic minorities (e.g., Bamiléké, Anglophones or Fulani Muslim groups), so this reasoning goes, require a certain minimum level of development to remain politically passive. (This narrative is quite surprising given that political-ethnic minorities in Cameroon often report the exact opposite.11)

In a series of striking conversations, a narrative emerged wherein abandonment was 
understood as tied to Nanga's particular socio-ethnic-political heritage. According to these accounts, the government did not perceive a need to develop rural places inhabited by people of predominantly Beti ethnic-political heritage, because they are expected to express a natural solidarity with the RDPC. The government expected that place-based ethnic-political identity would curtail the emergence of antistate dissent and, by extension, critique of state-sponsored projects. Indeed, a body of literature shows how elites control and access the state's distributive networks by selective manoeuvring of political-ethnic sentiments. Scholars document the co-optation of national and anticolonial cultures by the African bourgeoisie for its own class interests (Fanon, 1961; Cabral, 1979). Nyamnjoh and Rowlands (1998: 325) explain that in Cameroon:

Both the Ahidjo and Biya regimes [the country's first and second presidencies respectively] deliberately foster[ed] ethic conflict and prejudice...for the purpose of maintaining national unity... [This echoed] the colonial tactic of promoting tribalism as an excuse to crack down on political opposition in the name of national unity.

In this system, sentiments of loyalty are drawn upon to manage, assuage and distract from frustration and anger, often before protest occurs. An attention to the processes of co-optation of emotional attachment in neocolonial societies remains indispensable to understanding resistance politics (see Pearlman, 2013, for an analysis of such behaviour by authoritarian regimes in North Africa). In Cameroon, political leaders propagate a selective anti-imperial-nationalist discourse to build loyalty, as the same political leaders facilitate neoimperial plunder. This discourse becomes a mechanism through which grievances are displaced from the state onto another body, group or institution (in some cases onto other religious-politico-ethnic groups and in others, foreign neocolonial powers).

Moreover, the Cameroonian state barely tolerates collective dissent (Fombad \& Fonyam, 2004; Walla, 2012) in areas that are 'loyal' to the RDPC as well as those that have been historically (political and socially) marginalized throughout RDPC political dominance. The cyclical reshufflings of government cabinets speaks to Biya's aptitude for suppressing those he perceives as a political threat. The imprisonment of so many former government officials gave rise to the standing joke that Yaoundé's Kondengui Central Prison has all of the government officials necessary to run a government except the president. Many of these imprisoned former officials have been les ennemis dans la maison (enemies in the house) or former RDPC figureheads. This vindictive geopolitical landscape with 'shadow players' planning coups was described in leaked US diplomatic cables (Brown, 2008). With so many examples of the dangers of stepping out of line-including former Finance Minister Polycarpe Abah, former Minister of Finance and Secretary General at the Presidency Jean Marie Atangana Mebara, former Minister of Health Urbain Olanguena Awono, former Minister of Communication Gervais Mendo Ze, former Minister of Defense Remy Ze Meka and former Minister of State for Territorial Administration Hamidou Yaya Marafa-people were wisely cautious. Some reported feeling afraid to speak poorly of the government or afraid to condemn actions that might reflect poorly upon the government.

During a discussion with a group of people whose plantations had been destroyed and whose land was appropriated by the project near Nanga, Jean told me (farmer, pers. comm., Nanga, November 2012), 'You know, my daughter, the land there - it is the belly' (Figure 11). As he spoke he pointed to the dense forest of the Congo Basin behind us and then emphatically palmed his stomach. Seven of his friends and neighbours nodded and murmured in agreement. 'If you take it away-you feel it, you cannot forget it.

[For] all the days of our lives... we will always think of the pipe[line].' Jean's words reveal an indignant anger at the failure of the project to deliver its central promises of development. Although there was a collective anger that arose from dispossessions along the pipeline in Nanga, powerful place-based, ethnic-political sentiments created a landscape hostile to fast or immediate resistance. There is no monocausal explanation for why people do not resist when there is a collective anger founded on experiences of injustices and oppressions. In Nanga, broader emotional geographies of fear, loyalty and respect play important roles.

One man, Gabby, described the pipeline as 'unforgettable'. He and his family live with a combination of hope and anger: hope that things will be better one day and anger 
in an interim of waiting. Gabby's narrative is echoed by several of his neighbours, for whom the pipeline is narrated as a lost opportunity and a hopeful future. People had a sense that if a similar project comes to fruition people will have a better idea of the limited temporality of development promises or will recognize the importance of intervening or dissenting quickly to assert their rights.

When I inquired as to how a similar project would be received in the region, people unanimously said they would respond differently, because they have learned from this experience of the pipeline: 'Next time we will not be duped' and 'next time there will be violence. I will run them off my [farm] plot with a machete'. Pierre, for example, voiced mixed senses of anger and shame:

If they tell us the president decided to make another pipeline and the people were okay [with it], it would mean we are animals - like sheep. It is like a cockroach that you kill in your house, that would be us (farmer, pers. comm., Kribi, February 2013)!

Another man, Frank, was incensed and could not imagine 'allowing' such a project in the future. He said:

If they listen to us, I say never again! If we could un-bury it and send it to another country, I tell you, I would work for free! I would dig it up without any payment! It would be a collective party for everyone (farmer and former COTCO labourer, pers. comm., Kribi, February 2013)!

Next time, next time. So that while these shared emotions are potential platforms for longitudinal dissents, they are limited by a socio-political geography that fuses ethnicpolitical heritage with sentiments of allegiance and loyalty. While it is inherently difficult to anticipate a particular 'spark' that will 'wake people up' (to echo Jojo), these emotional narratives indicate that people are already 'awake', so to speak.

\section{'What door to knock on?': structural obstacles and slow dissent}

At the same time that emotional geographies cultivate slow dissent, larger structural issues present significant logistical dilemmas for resistance building. Structural violence is enacted and perpetuated, in part, through the division, subdivision, subcontracting and splicing of actors and actions across regional, national and international scales

Figure 11. 'The land is the belly.' (a) The pipeline terminal cuts through the forest near Bikolo, outside Kribi, as (b) a woman cooks kpwemm, a regional dish made of stewed manioc or cassava leaves. The inability to cultivate manioc along the pipeline's passage incited considerable anger among people in the villages near Nanga (see Murrey, 2015a). Photographs by author, 2012-13.

(Murrey, 2015b). Structural violence includes (1) the use of subcontractors and private firms ('shadow actors') that operate outside the oil consortium regulations to manage engineering, construction and labour; (2) the bureaucratization and outsourcing of decision making within institutions like the World Bank; and (3) the use of noncontractual, temporary, migrant and masculinized labour (which excludes women from networks of power and platforms for collective bargaining). These structures further fracture the potentials for collective or fast dissent. Additionally, while emotional narratives reveal potentials for slow dissent, they simultaneously expose the ability of corporate and governmental entities to control geographic flows of information, so that earlier social and environmental devastations of oil in other regions (for example, that effected through 60 years of oil extraction in the Niger Delta) did not inform resistance in Cameroon in the early 2000s. Indeed each successive discovery of oil seems to occur within sociopolitical amnesia: an isolated set of concerns and considerations sustains an unrelenting optimism (or, what Paul Hirt, 1994 has called a 'conspiracy of optimism') that each new discovery will somehow be 'the' exception to the rule that oil is accumulated through disaster, violence and risk (Figure 12).

Along the pipeline, community members and communities are affected unevenly, depending on their location along the pipeline, proximity to the pipeline within the village, gender, age, political connections or ethnic heritage. These discrete spatial experiences of the pipeline shape a person's understanding, knowledge, ideas and hopes of the pipeline in various ways. Not only are resistance strategies pluriform across space (the pipeline passes beneath 238 villages and is within $2 \mathrm{~km}$ of 794 additional villages), 
but also people's responses to the pipeline (from disregard to adaptive strategies to

Figure 12. 'Pssttt, psssst... think of future generations'. A section of a consciousness-raising comic strip from a Cameroonian non-governmental organization, the Foundation Camerounaise pour une Action Rationalisée des

Femmes sur l'Environnement (FOCARFE). FOCARFE focuses on the socio-environmental risks of the overexploitation

of forest resources. Source: FOCARFE.

resistance) are different within the same community. Spatial and geographical positioning shape people's conceptualizations of the pipeline differently (as both a material entity as well as their memories of engagement with the pipeline as an experience). This uneven incorporation into the pipeline project stymied fast, organized resistance: there was, in this sense, no uniform or collective 'we' across the 238 affected villages to articulate a unified experience of the pipeline.

Simultaneously, the project incorporated a large number of engineering, financing, implementation, construction, management, production and oversight agencies, institutions and companies - so much so that people reported being overwhelmed and unsure to whom to address complaints and in what manner to present them. I was told, 'On ne sais même pas à quelle porte cogner' (we do not even know what door to knock on). Indeed, David Harvey argues that 'resistance... comes from being able to recognise the real enemy amongst a frightening array of enemies' (quoted in Pile 1997: 5). In a village near Kribi, André reported that complaints had been filed on behalf of several community members. Unfortunately, he noted:

As for filing complaints, Oscar [the Community Relation Officer for Kribi] will always see you, but we cannot know at what level our complaints stop. People cannot continue to complain for the same problem every day, we don't have any idea what he does with complaints... They [COTCO] descend in the village when they decide and for what they deem necessary. They never respond directly to our complaints. They never respond directly to us at all (an unemployed man in his 30 s, pers. comm., Kribi, January 2013).

Similarly, a chief of a village nearby Kribi said:

I do not want to speak of COTCO, it hurts me. They did nothing for us. They destroyed plantations and wells... then they built a well that does not support all of the village. Before, the

water... was a clean water source... [but] we did not bring a complaint - to whom should we appeal for our rights? Because the project was approved by the state... [we could not turn to the state and] NGOs were unsuccessful in bringing change (pers. comm., village near Kribi, March 2013).

As the chief's words suggest, not only were people unsure about whom to approach, they were doubtful that complaints would be seriously considered, because of the state's endorsement of the project. In cases when people expressed an interest in taking action, they were uncertain how to organize collective or individual action. In this landscape, fast resistance is improbable.

\section{Conclusion}

A focus on emotion reveals three important aspects of slow dissent within geographies of structural violence. First, as feminist geographers have argued, there is inherent value in understanding the emotional geographies of political and social resistances. This article has provided a geographically informed analysis of two case studies of the role of emotions in shaping resistance geographies. The pain, anger, shame and struggles bound up within experiences of land dispossession and loss along the Chad-Cameroon Oil Pipeline are palpable through narrative recounting. The emotional narratives and struggles of people living along the pipeline offer important insights into the articulation of dissent against the slowly advancing violence(s) of neoliberal globalizing projects and militarized authoritarian states. Understanding life and struggle amid systemic violence is paramount for those concerned with understanding the human consequences of capitalist rearrangements of local geographies and lifescapes. Resistance in such cases is often slow and emerges within a context of powerful unifying emotions: grief, frustration, anger, dignity and hope. These struggles begin in the organic building of a collective emotional attentiveness or sensitivity to injustice and injury. 
Second, looking at emotions is important for studies of agency within socio-political and economic structures, including the shifting emotionality of the structures that make up structural violence. That structures encourage or trigger the production of particular emotions (and the repression of others) in-place is established in Edward S. Herman and Noam Chomsky's (1988) seminal work on the manufacturing of consent by the dominant structures of the US media, for example. Work on the emotionalities of geographies of structural violence raises questions about the emotionalities of people with institutional, economic and/or political power (i.e., the people who make up the structures of structural violence). This work would further expand the reconceptualization of power in noninstrumentalist terms. Ethnographic work with employees 12 of the World Bank has shown that there is no monocausal explanation for people's participation in oppressive institutions, but we still know little about the emotionality of such participation (see Goldman, 2006; see Peet, 2003 for an analysis of the World Bank as an oppressive institution; see John Perkins, 2004 for an autobiographical account of work as an 'economic hit man' funnelling money from institutions like the World Bank; see Arthur Mason, 2015 for an examination of the emotional landscapes of 'event collectives' within the oil industry).

Third, work on emotional geographies of resource extraction reveals an urgent need for ways of healing. The great scholar of Peace Studies, Johan Galtung, coined the theory of structural violence, which I broadly employ in my work, and there is a need to return to this genealogy of peace and healing. Geographers are increasingly attuned to the needs of care, healing and peace (Daley, 2008; 2014; Raghuram et al., 2009); from this literature, we might more fully consider the need to restore pride after dehumanizing experiences. This would mean working to empower collective selves through the creation of social structures that recognize humanity. There is potential within the increasing calls for slowing down the research process (Darab, 2012; Gurr, 2014; Mountz et al., 2015) for the accommodation of a different research temporality that allows for fine-grained, slow attention to social movement making over space and time. Rather than simply responding to the emotional, psychological and practical needs of the researcher, slow scholarship enables us to make meaningful relationships with the people in the communities where we research (see Gurr, 2014)-relationships that begin the important work of decolonizing the uneven power dynamics in research processes. Practices of slow scholarship allow researchers to address the long-term needs of the communities where we work. In this way, my reflections here are tentative and humble; they emerge alongside my commitment to pursue slow scholarship in Nanga and Kribi.

Mahmood Mamdani (2012) argues that dominant social science paradigms, including the imperative for universalism and standardization, have meant that academics fail to sufficiently anticipate revolutionary momentum. My reflection here was sparked by my desire to attend to emotional narratives of resistance alongside a salient lack of direct, fast, organized resistance. Engaging with anger, pain and disappointment reflects the intricate emotionality of life in extractive landscapes. When considered in tandem, these shared narratives indicate place-based collective emotional scripts that illuminate possibilities of oscillating and incomplete slow dissent. At the same time, I cannot end my reflection triumphantly. The pipeline has not been the project to spark resistance; rather, part of conceptualizing slow dissent is recognizing that there might not be one capturable or calculable moment, exploitation, expulsion, dispossession or catalyst for a revolutionary or system-altering resistance. A framework of slow dissent requires that we look holistically at geography: in isolation, none of these emotional narratives radically alter the socio-political landscape of Cameroon. Considered together, they reveal shifting emotionalities of slow dissent.

\section{Acknowledgements}

I would like to thank all of the people in the villages near Nanga and Kribi who opened their homes, kitchens, plantations and lives to me as we walked, ate, gathered and talked about the pipeline, politics and more. Fieldwork for this article was funded by a Clarendon Fellowship at the University of Oxford, and the final write-up year for this research was funded by a 2014/15 Dissertation WriteUp Fellowship in African and African Diaspora Studies (AADS) at Boston College. I am grateful for the insightful feedback on earlier drafts of this article or the ideas herein from Derogy Ndewa, Maimuna Islam, Nicholas A. Jackson, Richard Powell, Patricia Daley and Patricia Noxolo. Finally I am thankful for the commentary from participants at Boston College's AADS Fall 2014 Works in 
Progress Series and the graduate students who attended Boston University's 2015 African Studies Graduate Student Conference, during which I presented earlier versions of this article. All errors are of course my own.

\section{Endnotes}

1 Fieldwork for this project built upon five previous years of living in and/or working on Cameroon and included participant observation, informal and formal interviews, group discussions and the making of an ethnographic film and its subsequent screening within the community.

2 See Campbell \& Murrey, 2015 for an analysis of the socio-political consequences of US-backed militarization of Africa for resistance movements.

3 For a detailed examination of this literature, see Jasper, 2011.

4 See Murrey (2015b: 63-99) for a detailed discussion of my decolonial mixtape, including my use of filmmaking and film screening during fieldwork. A portion of this film is available at https:// www.youtube.com/watch?v=3OafTAQiyms.

5 A coalition of non-profit organizations led a series of campaigns to halt the pipeline project, asserted demands on behalf of forest people and brought attention to the gendered inequalities of the pipeline (see Hoinathy, 2013).

6 The government of Chad holds marginal interests in both TOTCO and COTCO, while Cameroon holds interests in COTCO alone (both companies are jointly managed subsidiaries of ExxonMobil). Petronas and ExxonMobil jointly hold the remaining (majority) shares in these two pipeline operating companies. At the same time, the pipeline is operated through Esso Exploration and Production Chad, Inc. (i.e., Esso Chad) - ExxonMobil is the parent company of Esso

Chad.

7 The World Bank provided International Bank for Reconstruction and Development (IBRD) loans in the amounts of USD 39.5 million to Chad to finance holdings in TOTCO and COTCO and USD 53.4 million to Cameroon to finance holdings in COTCO (World Bank, n.d.). The remainder of the project was financed jointly by the oil consortium as well as by other financial institutions, including the European Investment Bank.

8 The resource curse refers to an overdependence on revenues from resources, lack of economic investment in other sectors and increases in poverty, violence and conflict that are associated with resource extraction (see Obi, 1997 for a challenge to this paradigm).

9 All names are pseudonyms.

10 Cameroon's current land tenure laws are based on colonial land law, which remained unchanged in the postcolonial period. During colonialism, colonial administrators imposed a Slow dissent 245

system of eminent domain, which facilitated the large-scale appropriation of native lands under the guise of public interest (see Nguiffo, 1998: 107-109; Endeley, 2010).

11 For example, when I met Ni John Fru Ndi, the founder of Cameroon's major political opposition party, the Social Democratic Front (SDF), in late 2007, he asserted that the infrastructural underdevelopment of the cities of the southwest provinces, namely Bamenda, was due to animosities from le système Biya (the Biya system) towards Bamenda's majority Anglo-Bami (i.e., Anglophone-Bamiléké) population.

12 There are currently 15551 Bank employees (not counting its 19608 contract workers).

\section{References}

Adunbi O (2013) Mythic oil: resources, belonging and the politics of claim making among the İlàję Yorùbá of Nigeria. Africa: The Journal of the International African Institute 83 (2), 293-313. Amin J (2004) Paul Biya's foreign policy: the promise and performance. In Mukum Mbaku J, Takougang J (eds) The Leadership Challenge in Africa: Cameroon under Paul Biya, 153-90. Africa World Press, Trenton, NJ.

Anderson K, Smith S J (2001) Emotional geographies. Transactions of the Institute of British Geographers 26, 7-10.

Bayat A (2010) Life as Politics: How Ordinary People Change the Middle East. Amsterdam University Press, Amsterdam.

Bondi L, Davidson J, Smith M (2007) Introduction: geography's emotional turn. In Davidson J,

Bondi L, Smith M (eds) Emotional Geographies, 1-16. Ashgate, Aldershot.

Brown PT (2008) Through a glass darkly: tracing Cameroon's political undercurrents. Wikileaks Cable: 08YAOUNDE237, Classification 'Secret'. Available at: https://wikileaks.org/plusd/cables/ 08YAOUNDE237_a.html (accessed 16 March 2016).

Cabral A (1979) Unity and Struggle: Speeches and Writings. Wolfers M (trans). Monthly Review Press, London and New York.

Campbell H, Murrey A (2015) Culture-centric preemptive counterinsurgency and US Africa

Command: assessing the role of the US social sciences in military engagements in Africa. Third

World Quarterly 35 (8), 1457-75.

Daley P (2008) Gender and Genocide in Burundi: The Search for Spaces of Peace in the Great Lakes Region.

James Currey, Oxford.

Daley P (2014) Unearthing the local: hegemony and peace discourses in Central Africa. In Megoran

N, Williams P, McConnell F (eds) Geographies of Peace, 66-88. IB Tauris, London.

Danaher K (1994) 50 Years is Enough: The Case against the World Bank and the International Monetary

Fund. South End Press, Boston. 
Darab S (2012) A call for slow scholarship: a case study on the intensification of academic life and its implications for pedagogy. Review of Education, Pedagogy, and Cultural Studies 34 (1-2), 49-60.

Endeley JBM (2010) The politics of gender, land and compensation in communities traversed by the Chad-Cameroon Oil Pipeline. In Tsikata, Dzodzi and Pamela Golah (eds) Land Tenure, Gender and Globalisation: Research and Analysis from Africa, Asia and Latin America, 145-79. ZUBAAN and Kali for Women, New Delhi.

Eshun G, Madge C (2012) "Now let me share this with you": exploring poetry as a method for postcolonial geography research. Antipode 44 (4), 1395-1428.

Esso Exploration and Production Chad (n.d.) Consortium. Available at: http://www.essochad.com/ Chad-English/PA/About/TD_Consortium.aspx (accessed 9 March 2016).

ExxonMobil (2004) 2004 ExxonMobil corporate responsibility report 2004. Available at:http://corporate. exxonmobil.com/ /media/Reports/Corporate\%20Citizenship\%20Report/2004/ ccr04_full_report.pdf(accessed 14 November 2014).

Fanon F (1961) The Wretched of the Earth. Grove Press, New York.

Fombad CM, Fonyam JB (2004) The Social Democratic Front: the opposition and the transition. In Mbaku JM, Takougang J (eds) The Leadership Challenge in Africa: Cameroon under Paul Biya, 453-88. Africa World Press, Trenton, NJ.

Gibson C (2006) Decolonizing the production of geographical knowledges? Reflections on research with indigenous musicians. Geografiska Annaler Series B 88 (3), 277-84.

Gilmartin M (2009) Border thinking: Rossport, Shell and the political geographies of a gas pipeline. Political Geography 28, 274-82.

Goldman M (2006) Imperial Nature: The World Bank and Struggles for Social Justice in the Age of Globalization. Yale University Press, New Haven.

Gurr B (2014) Ten years on: making relatives and making meaning in the borderlands. Critical Sociology 40 (1), 151-68.

Herman E, Chomsky N (1988) Manufacturing Consent: The Political Economy of the Mass Media.

Pantheon Books, New York.

Hibou B (2012) The Tunisian revolution did not come out of nowhere: Sadri Khiari speaks to

Béatrice Hibou. In Ekine S, Manji F (eds) African Awakening: The Emerging Revolutions, 218-30.

Pambazuka Press, Cape Town, Dakar, Nairobi and Oxford.

Hirt P (1994) A Conspiracy of Optimism: Management of the National Forests since World War Two. University of Nebraska Press, Lincoln.

Hoinathy R (2013) Pétrole et changement social au Tchad. Karthala, Paris.

International Advisory Group (2009) Chad-Cameroon petroleum development and pipeline project.

Final report. Available at: http://web.worldbank.org/archive/website01210/WEB/IMAGES/

IAG_CHAD.PDF (accessed 23 August 2015).

International Finance Corporation (2001) IFC signs loan for Chad-Cameroon Pipeline Project. Available

at: http://ifcext.ifc.org/ifcext/pressroom/ifcpressroom.nsf/1f70cd9a07d692d685256ee1001cdd37/69

d3e7e2c40eae6185256a72007085d2?OpenDocument (accessed 9 March 2016).

Jackson N (2011) Neoliberalism as spectacle: economic theory, development and corporate exploitation.

Human Geography-A Radical New Journal 4 (3), 1-13.

Jasper J (2011) Emotions and social movements: twenty years of theory and research. Annual Review of Sociology 37, 285-303.

Kara H (2015) Creative Research Methods in the Social Sciences: A Practical Guide. Policy Press, Bristol and Chicago.

Malaquais D (2002) Blood money: a Douala chronicle. In Ntone E, Edgar P (eds) African Cities Reader, 137-49. African Centre for Cities, University of Cape Town, Cape Town.

Mamdani M (2012) An African reflection on Tahrir Square. In Manji F, Ekine S (eds) African

Awakening: The Emerging Revolutions, 198-210. Pambazuka Press, Cape Town, Dakar, Nairobi and Oxford.

Mason A (2015) Events collectives: The social life of a promise-disappointment cycle. In Appel H, Mason A, Watts M (eds) Subterranean Estates: Life Worlds of Oil and Gas, 325-39. Cornell University Press, Ithaca and London.

MbuagboO T,Mbe Akoko R (2004) Roll-back: democratization and social fragmentation in Cameroon. Nordic Journal of African Studies 13 (1), 1-12.

Mngxitama A (2013) Not only our land but also our souls. Chimurenga Chronic 1, 10.

Mountz A, Bonds A, Mansfield B et al. (2015) For slow scholarship: a feminist politics of resistance through collective action in the neoliberal university. ACME: An International E-Journal for Critical Geographies 14 (4), 1208-234.

Murrey A (2012) Thoughts on thirty years of Biya power in Cameroon. Pambazuka Press 605.

Available at: http://www.pambazuka.net/en/category.php/features/85296/print (accessed 23

August 2015).

Murrey A (2015a) Narratives of life and violence along the Chad-Cameroon Oil Pipeline. Human Geography-A New Radical Journal 8 (1), 15-39.

Murrey A (2015b) Lifescapes of a Pipedream: A Decolonial Mixtape of Structural Violence and Resistance in Two Towns along the Chad-Cameroon Oil Pipeline (PhD dissertation). School of Geography and the Environment, University of Oxford, Oxford.

Murrey A (2015c) Invisible power, visible dispossession: the witchcraft of a subterranean pipeline. Political Geography 47, 64-76. 
Murrey A (forthcoming) A post/decolonial geography beyond 'the language of the mouth'. In Woons M, Weier S (eds) Borders, Borderthinking, Borderland: Developing a Critical Epistemology of Global Politics. E-International Relations Publishing.

Nguiffo S (1998) In defence of the commons: forest battles in southern Cameroon. In Goldman M (ed) Privatizing Nature: Political Struggles for the Global Commons, 102-19. Rutgers University Press, New Brunswick.

Nguiffo S (2002) Traversing people's lives: how the World Bank finances community disruption in Cameroon. Frijns J (eds). Center for the Environment and Development, Yaoundé. Available at: http://www.foei.org/wp-content/uploads/2014/08/traversing.pdf (accessed 16 March 2016).

Nixon R (2011) Slow Violence and the Environmentalism of the Poor. Harvard University Press, Cambridge, MA.

Nyamnjoh F B, Rowlands M (1998) Elite associations and the politics of belonging in Cameroon. Africa: Journal of the International African Institute 68 (3), 320-37.

Obi C (1997) Globalisation and local resistance: the case of the Ogoni versus Shell. New Political Economy 2 (1), 137-48.

Ola D, Eighemhenrio D (1998) Wasting lives: official negligence results in grave tragedy at Idjerhe, Niger Delta, Nigeria. Association of Nigerian Scholars for Dialogue. Available at: http://www.waado. org/nigerian scholars/archive/opinion/idjerhewast.html(accessed 19 November 2014).

Osuoka I, Zalik A (2010) The dilemmas of global resistance against extractive capital: the Oilwatch Network in Africa. Canadian Journal of Development Studies 1(2), 237-57.

Pearlman W (2013) Emotions and the microfoundations of the Arab uprisings. American Political Science Association 11 (2), 387-409.

Peet R (2003) The Unholy Trinity: The IMF, World Bank and WTO. Zed Books, London.

Perkins J (2004) Confessions of an Economic Hit Man. Berrett-Koehler Publishers, San Francisco.

Pettigrove G, Parsons N (2012) Shame: a case study of collective emotion. Social Theory and Practice 38 (3), 504-30.

Pile S (1997) Introduction: Opposition, political identities and spaces of resistance. In Pile S, Keith M (eds) Geographies of Resistance, 1-32. Routledge, London and New York.

Raghuram P, Madge C, Noxolo P (2009) Rethinking responsibility and care for a postcolonial world. Geoforum 40 (1), 5-13.

Sharp J, Routledge P, Philo C, Paddison R (2000) Entanglements of power: geographies of domination/resistance. In Sharp J, Routledge P, Philo C, Paddison R (eds) Entanglements of Power: Geographies of Domination/Resistance, 1-42. Routledge, London and New York.

Sharp J (2009) Geography and gender: what belongs to feminist geography? Emotion, power and change. Progress in Human Geography 33 (1), 74-80

Taguem Fah G L (2007) The war on terror, the Chad-Cameroon Pipeline, and the new identity of the Lake Chad Basin. Journal of Contemporary African Studies 25 (1), 101-17.

Toila-Kelly D P (2006) Affect - an ethnocentric encounter? Exploring the 'universalist' imperative of emotional/affectual geographies. Area 38 (2), 213-17.

Toussaint E (2008) The World Bank: A Critical Primer. Pluto Press, London and Ann Arbor. Walla K (2012) 'The power is within us': a protest diary from Cameroon. In Manji F, Ekine S (eds) African Awakening: The Emerging Revolutions, 107-10. Pambazuka Press, Cape Town, Dakar, Nairobi and Oxford.

World Bank (2008) World Bank press release - statement on Chad-Cameroon Pipeline 2009/073/ AFR. Available at: http://web.worldbank.org/archive/website01210/WEB/0_CO-20.HTM (accessed 9 March 2016).

World Bank (n.d.) Project description. Available at: http://web.worldbank.org/archive/website01210/ WEB/0_CO-15.HTM (accessed 16 March 2016).

Wright $\overline{\mathrm{S}}(2012)$ Emotional geographies of development. Third World Quarterly 33 (6), 1113-27. 